\title{
Conceiving After Management of Infertility Without Assistance in a Low-Income Area
}

\author{
Dr Bakhtawar Fatima ${ }^{1}$ Dr Hafiz Kazim Hassan ${ }^{2} \quad$ Dr Maria Iqbal Khan ${ }^{2}$ \\ 1.Mayo Hospital and Lady Willingdon Hospital, Lahore \\ 2. Khyber Teaching Hospital, Peshawar
}

\begin{abstract}
Getting pregnant after infertility management is a more challenging situation in some under equipped sub-Saharan setting. To highlight the determinants of conception without Assisted Reproductive technology (ART) in a lowincome area. The current study concerned 2958 patients who sought care for infertility in the Mayo Hospital, Lady Willingdon Hospital Lahore and Khyber Teaching Hospital, from January 2018 to December 2018. For them, any technique of ART was used. Age of patients ranged from 18 to 49 with average of $33.2 \pm 5.6$ years old. After treatment, 249 (9\%) patients conceived (clinical pregnancy). Most of the patients who conceived were less than 36 years, without history of illegal abortions et who suffered from genital infections. The treatments closely associated with conception were antibiotics (73\%), hydrotubation (12\%) ovulation inductors (11\%) and gynecologic surgery (4\%). In that setting, ART is a must. Very few infertility problems, apart from infection and its consequences, can get solution
\end{abstract}

Keywords: Conceiving, Infertility Management, Low Income Area, ART, Tubal Infertility

DOI: $10.7176 / \mathrm{JMPB} / 60-05$

Publication date:October $31^{\text {st }} 2019$

\section{Introduction}

Getting pregnant after infertility management is a more challenging situation in some under equipped area. In spite of the high prevalence of infertility $(25 \%-30 \%)$, relevant care, represented by Assisted Reproductive techniques (ART) are not only generally unavailable, but more expensive in most of those settings where they are implemented [1] [2]. Resorting to former attitudes without ART is then the rule.

Couple infertility, defined as the failure to conceive after at least a year of regular and complete intercourse without any contraception, is a worldwide public health problem [3] [4] [5] ; especially in sub Saharan setting [6] . The tuboperitoneal lesions from infectious origin constitute the main cause of infertility [7]. That region is among pronatalists areas where infertility is a source of social dramatic consequences like: stigmatization, reject, divorce, polygamy and depression [8] [9]. Belonging to a strong growth demographic region, secondary infertility is the most prevalent. Indeed, with a high desire to procreate, there is less attention to use contraceptive method, like barrier, that prevent also from sexual transmitted infection (STI) [10] .

The STI with postpartum infection are the main cause of tubal infertility by tubal occlusion among with, peritoneal and peritubo ovarian adhesions. Assisted Reproductive Techniques (ART) constitutes the relevant way to take care of those patients. Unfortunately, they are unavailable in some sub-Saharan areas because of the difficulties to acquire equipment; and the way many government's decision makers perceive the problem of infertility [2] [11]. According to WHO, the Reproductive health is a complete well being of people concerning genital apparatus: its function and its functionality, not only the absence of disease. That definition takes in account, couple infertility and its consequences [12]. Unfortunately, in many sub-Saharan countries, Reproductive health is reduced to contraception methods. So, organizing facilities to take care of infertility is considered as spending money for free. In the other hand, ARTs are so expensive (cost of ovulation inductors and investigations) that few can afford that by themselves [11]. In that situation many medical institutions providing infertility care don't dispose of ART facilities.

Until 2013, more than 450 ART centers were available in USA, with 12,000 dollars for one tentative; supported by the patient; in France, 106 centers with $2500 \$$ a tentative, supported by social security facilities [13] [14] [15] . In Africa continent, few centers providing ART were available [16] [17] : three in Kenya and one in DRC, where cares are supported by the patients themselves. Consequently, many infertile patients were treated without using ARTs.

The aim of the current study is to highlight the determinants of conception in a program of infertility management out of ARTs, in a low-income setting.

\section{Results}

1) General patients' characteristics

The mean age of patients was $33.2 \pm 5.6$ years and ranged from 18 to 49 years old. Most of them (34.3\%) were above 35 years, followed by those between 31 to $35(32.1 \%)$. The mean age of menarche was $13.8 \pm 1.8$ years ranging from 8 to 22 years. The majority of patients were nulliparous $(62.9 \%)$, three percent $(2.8 \%)$ were 
multiparous and two third (65.6\%) had secondary infertility. Forty percent of the patients had a history of at least one illegal abortion. Almost all of them $(97.4 \%)$ were married.

The male partners mean age was $40.3 \pm 6.3$ years old with the extreme of 24 and 74 years. The majority of them $(51.7 \%)$ were between 31 and 40 years old. Mean infertility duration was $4.3 \pm 3.7$ years with a quarter $(26.6 \%)$ having consulted after 5 years of infertility. Forty-one percent had a history of previous abdomno pelvic surgery, among them appendicectomy $(13 \%)$ and myomectomy $(8.9 \%)$ were the most frequent. Most of patients were overweight $(39.6 \%)$ and a fifth $(20.1 \%)$ frankly obese.

After first visit and preliminary investigations, genital infection (low and high genital infection) was the most frequent main diagnosis $(46.7 \%)$ followed by uterus myoma $(21.9 \%)$.

At hysterosalpingography (for 1219 patients) almost a half (46.5\%) had tubal occlusion with 33.5\% bilateral occlusion. The endometrial biopsy revealed 43 (5.04\%) patients with endometritis; among them 38 cases $(88.3 \%)$ of nonspecific endometritis and 2 (4.6\%) of tuberculosis endometritis. Among the 647 spermograms, $75 \%$ were abnormal $\quad(52 \% \quad$ oligoasthenozoospermia, $\quad 18 \% \quad$ oligozoospermia; $4 \% \quad$ azoospermia $\quad$ and $\quad 1 \%$ oligoasthenoteratozoospermia). According to the diagnosis, different treatments were applied

\begin{tabular}{|c|c|c|c|c|}
\hline Variables & OR & SE & $\mathbf{p}$ & IC $95 \%$ \\
\hline \multicolumn{5}{|l|}{ Age of patientes (years) } \\
\hline$<25$ & 24.350 & 32.577 & 0.017 & $\begin{array}{l}1.768- \\
335.203\end{array}$ \\
\hline $26-30$ & 1.731 & 1.616 & 0.556 & $\begin{array}{l}0.278- \\
10.786\end{array}$ \\
\hline $31-35$ & 5.935 & 4.802 & 0.028 & $\begin{array}{l}1.215 \\
28.984\end{array}$ \\
\hline $\begin{array}{c}>35 \\
\text { Type of infertility }\end{array}$ & 1 & & & \\
\hline Infer II & 1.952 & 1.233 & 0.290 & $\begin{array}{l}0.565- \\
6.738\end{array}$ \\
\hline $\begin{array}{c}\text { Infer I } \\
\text { megal abortions }\end{array}$ & 1 & & & \\
\hline $1-2$ & 1.460 & 1.169 & 0.636 & $\begin{array}{l}0.303- \\
7.014\end{array}$ \\
\hline 23 & $\begin{array}{c}1 \\
\text { (omitted) }\end{array}$ & & & \\
\hline $\begin{array}{c}\text { None } \\
\mathrm{BMI}\left(\mathrm{Kg} / \mathrm{m}^{2}\right)\end{array}$ & 1 & & & \\
\hline $18.5-24.9$ & 0.108 & 0.139 & 0.085 & $0.008-$ \\
\hline $25-29.9$ & 0.057 & 0.077 & 0.033 & $\begin{array}{l}0.004- \\
0.795\end{array}$ \\
\hline$\geq 30$ & 0.308 & 0.421 & 0.389 & $\frac{0.021-}{4.485}$ \\
\hline $\begin{array}{l}<18.5 \\
\text { Endometrial biopsy }\end{array}$ & 1 & & & \\
\hline Functional abnormalies & 0.437 & 0.333 & 0.278 & $\begin{array}{l}0.982- \\
1.948\end{array}$ \\
\hline Endometritis & 11.837 & 19.932 & 0.142 & $\begin{array}{l}0.436- \\
321.057\end{array}$ \\
\hline $\begin{array}{c}\text { Normal } \\
\text { Spermogram }\end{array}$ & 1 & & & \\
\hline Oligospermia & 0.970 & 0.908 & 0.974 & $\begin{array}{l}0.154- \\
6.084\end{array}$ \\
\hline Oligoasthenozoospermia & 0.521 & 0.355 & 0.339 & $\begin{array}{l}0.137- \\
1.979\end{array}$ \\
\hline OAT & (omitted) & & & \\
\hline Azoospermia & (omitted) & & & \\
\hline $\begin{array}{c}\text { Normal } \\
\text { Infertility duration } \\
\text { (years) }\end{array}$ & 1 & & & \\
\hline 1 & 1.951 & 1.777 & 0.463 & $\begin{array}{l}0.327- \\
11.627\end{array}$ \\
\hline 2 & 1.736 & 1.490 & 0.520 & $\begin{array}{l}0.322- \\
9.337\end{array}$ \\
\hline $3-5$ & 1.416 & 1.127 & 0.662 & $\begin{array}{l}0.297- \\
6.737\end{array}$ \\
\hline $\begin{array}{l}>5 \\
\text { HSG }\end{array}$ & 1 & & & \\
\hline вто & 0.406 & 0.274 & 0.183 & $\begin{array}{l}0.108- \\
1.528\end{array}$ \\
\hline что & 3.656 & 3.551 & 0.182 & $\begin{array}{l}0.544- \\
24.537\end{array}$ \\
\hline Others & 0.112 & 0.123 & 0.046 & $\begin{array}{l}0.013- \\
0.965\end{array}$ \\
\hline
\end{tabular}

2) Conception among those patients

From the 2913 patients who attending infertility clinic, 249 conceived (9\%). To consider the treatment immediately followed by conception, we had antibiotics in $73 \%$ patients, ovulation inductors in $11 \%$, the actually abandoned hydrotubation in $12 \%$ and surgery in $4 \%$ (Figure 1 ). 


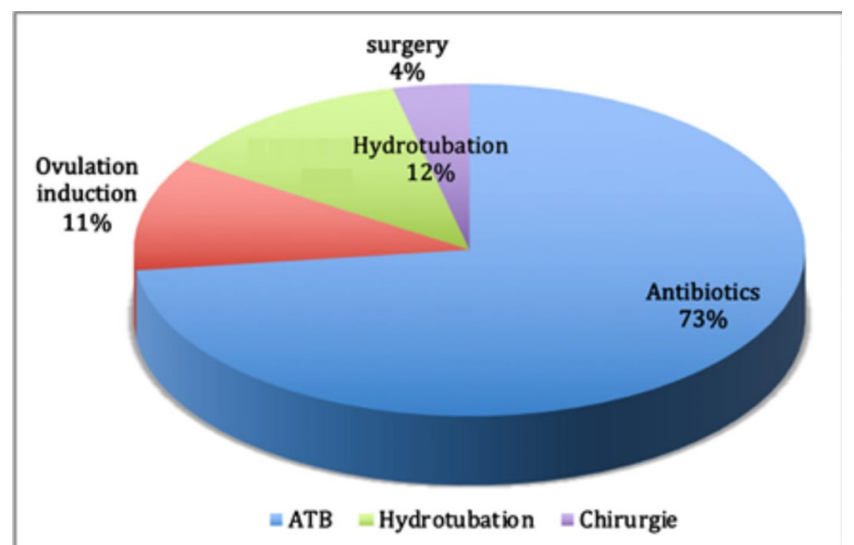

Mean age of the case group was lesser $(31.3 \pm 5.0$ years) than the control $(33.4 \pm 5.6$ years $)(p=0.000)$. Furthermore, the case group partners mean age was lesser ( $37.8 \pm 5.7$ years) than the controls partners $(40.5 \pm 6.0)$ $(p=0.000)$. According to Table 1 , below 36 years, $11 \%$ of patients conceived vs $4.2 \%$ above $(p=0.000)$. There was no difference $(\mathrm{p}=0.5)$ between the rate of conception between primary infertility patients $(9.3 \%)$ compared to secondary $(8.6 \%)$. Illegal abortion was more $(p=0.000)$ frequent $(41.2 \%)$ among the controls than the cases (27.54\%). The conception frequency decreased with the number of illegal abortion $(\mathrm{p}=0.000)$ : from $14 \%$ for patients without history of illegal abortion to $5 \%$ for the ones with more two abortion (Table 2).

\begin{tabular}{|c|c|c|c|c|}
\hline Variables & OR & SE & $\mathbf{p}$ & IC $95 \%$ \\
\hline \multicolumn{5}{|l|}{$\begin{array}{l}\text { Age of patients } \\
\text { (years) }\end{array}$} \\
\hline$\leq 25$ & 2.867 & 0.739 & 0.000 & $\begin{array}{c}1.729- \\
4.754\end{array}$ \\
\hline $26-30$ & 2.906 & 0.569 & 0.000 & $\begin{array}{c}1.978- \\
4.268\end{array}$ \\
\hline $31-35$ & 2.640 & 0.503 & 0.000 & $\begin{array}{c}1.816- \\
3.836\end{array}$ \\
\hline $\begin{array}{l}\quad>35 \\
\text { Type of infertility }\end{array}$ & 1 & & & \\
\hline Infer II & 0.909 & 0.127 & 0.499 & $\begin{array}{l}0.691- \\
1.197\end{array}$ \\
\hline $\begin{array}{c}\text { Infer I } \\
\text { Illegal abortion }\end{array}$ & 1 & & & \\
\hline $1-2$ & 0.586 & 0.100 & 0.002 & $\begin{array}{l}0.419- \\
0.820\end{array}$ \\
\hline$\geq 3$ & 0.329 & 0.141 & 0.009 & $\begin{array}{l}0.142- \\
0.762\end{array}$ \\
\hline \multicolumn{5}{|l|}{ Partner age (years) } \\
\hline$\leq 30$ & 1.714 & 0809 & 0,254 & $\begin{array}{l}0.679- \\
4.324\end{array}$ \\
\hline $31-40$ & 2.002 & 0714 & 0,052 & $\begin{array}{c}0.995- \\
4.029\end{array}$ \\
\hline $41-50$ & 0.578 & 0222 & 0,155 & $\begin{array}{l}0.272- \\
1.230\end{array}$ \\
\hline$>50$ & 1 & & & \\
\hline $18.5-24.9$ & 0.525 & 0.331 & 0.307 & $\begin{array}{l}0.152- \\
1.808\end{array}$ \\
\hline $25-29.9$ & 0.520 & 0.107 & 0.002 & $\begin{array}{l}0.347- \\
0.779\end{array}$ \\
\hline$\geq 30$ & 0.442 & 0.119 & 0.003 & $\begin{array}{l}0.260- \\
0.752\end{array}$ \\
\hline $\begin{array}{l}<18.5 \\
\text { Diagnosis }\end{array}$ & 1 & & & \\
\hline Genital infection & 1.829 & 0.758 & 0.146 & $\begin{array}{l}0.810- \\
4.125\end{array}$ \\
\hline Myoma & 1.134 & 0.526 & 0.785 & $\begin{array}{l}0.456- \\
2.810\end{array}$ \\
\hline Ovarian Dystrophy & 3.289 & 1.555 & 0.012 & $\begin{array}{c}1.301- \\
8.311\end{array}$ \\
\hline Hyperprolactinemia & 4.902 & 2.350 & 0.001 & $\begin{array}{l}1.915- \\
12.548\end{array}$ \\
\hline Synechia & 2.038 & 1.345 & 0.281 & $\begin{array}{l}0.559- \\
7.429\end{array}$ \\
\hline Menopausis & Omitted & & & \\
\hline Cycle desorders & 3.668 & 2.197 & 0.030 & $\begin{array}{l}1.133- \\
11.869\end{array}$ \\
\hline $\begin{array}{l}\text { Others } \\
\text { HSG }\end{array}$ & 1 & & & \\
\hline вто & 0.814 & 0.172 & 0.332 & $\begin{array}{l}0.537- \\
1.233\end{array}$ \\
\hline UTO & 0.689 & 0.210 & 0.223 & $\begin{array}{l}0.378- \\
1.254\end{array}$ \\
\hline Others & 0.459 & 0.142 & 0.012 & $\begin{array}{l}0.250- \\
0.844\end{array}$ \\
\hline $\begin{array}{c}\text { Normal } \\
\text { Endometrial biopsy }\end{array}$ & 1 & & & \\
\hline $\begin{array}{l}\text { Functional } \\
\text { abnormalies }\end{array}$ & 0.754 & 0.194 & 0.273 & $\begin{array}{l}0.455- \\
1.249\end{array}$ \\
\hline
\end{tabular}


Almost all the patients were married (99.15\% vs 97.21\%); no difference between married and singles for conception rate $(p=0.075)$. The percentage of the patients who conceived decreased steadily $(p=0.000)$ with the infertility duration.

Legend: OAT $=$ oligoasthenozoospermia; $\mathrm{BTO}=$ Bilateral tubal occlusion; $\mathrm{UTO}=$ Unilateral tubal occlusion; Others = synechiae, spicules. $21.5 \%$ after a year; $16 \%$ after two years and $7 \%$ after 5 years).

A third of the two groups (34.2\% and 39.6\%) had a history of abdomino-pelvic surgery, with appendicectomy as the most frequent $(13 \%)$. There was no difference $(\mathrm{p}=0.150)$ between the surgeries indication and the conception rate.

The mean BMI of the case group $(25.23 \pm 4.3)$ was less $(p=0.0014)$ than controls' $(26.73 \pm 5.18)$. Obesity was more frequent $(21.28 \%$ vs $13.92 \%)$ among controls $(p=0.0014)$ than case group. In comparison with the normoweighted group; the rate of conception was low in thinness category and decreased with the BMI above 30 $\mathrm{kg} / \mathrm{m} 2$ (0.001). Genital infection, after physical examination and first line investigations, was the main diagnosis $(22.67 \%$ vs $17.68 \%)$ but more frequent among the ones who conceived $(0.000)$; and myoma more frequent in control group $(8.66 \%$ VS $6.88 \%)(p=0.000)$. According to Table 2 , there was no difference between case group and control regarding HSG $(\mathrm{p}=0.073)$ and endometrial biopsy $(\mathrm{p}=0.059)$ findings for conception. The majority patients (44.45\% vs $46.5 \%$ had any tubal occlusion (bilateral tubal occlusion: $34.39 \%$ vs $33.39 \%$ ). A tenth (12\%) of patients with BTO conceived. Among the patients with endometritis, sixteen percent conceived after treatment. 3) Determinants of Conception

The variables significantly associated with conception were the age of patients and of their partners, BMI and the number of illegal abortions.

Patients of less than 36 years old had three times more chance to conceive than the ones above; especially for those of 25 - 30 years cluster $(\mathrm{OR}=2.9 ; 95 \% \mathrm{IC}: 1.978-4.286)$. Overweight and obesity were associated with the reduction of the chance of conception in comparison to the thinness $(p=0.002$ and $p=0.03)$. The chance of conception decreased with the number of illegal abortions: a history of 1 to 2 abortion reduced the chance of conception of $42 \%(p=0.002)$ and $70 \%(p=0.009)$ from 3 abortions. Patients whose male partners was less than 41 years old had twice more chance to conceive compared to those whose partners had more than 40 years old; this association was at the edge of significance $(p=0.052)$.

The chance to conceive decreased with the duration of infertility: one year, two and 3 to 5 years clusters were associated with respectively four, three and two times more chance to conceive than the ones above 5 years $(p=$ 0.000). Patients with tubo-peritoneal lesions at HSG had the chance of conception decreased of $20 \%$ for BTO; $30 \%$ for UTO and 55\% for others (deformation of uterine cavity, adenomyosis) compared with those without.

In multivariate analysis (Table 3$)$, the age of patients, the BMI remained significantly $(\mathrm{p}=0.017$ and 0.028$)$ associated with conception. In comparison with those of more than 35 years, patients of less than 25 and $31-35$ clusters had respectively 24 and 6 times more chance to conceive $(p=0.017$ and 0.028$)$. The chance of conception was reduced by $95 \%$ for overweight patients $(p=0.033)$ than the thins. 


\begin{tabular}{|c|c|c|c|c|}
\hline Variables & OR & SE & $\mathbf{p}$ & IC $95 \%$ \\
\hline \multicolumn{5}{|l|}{$\begin{array}{l}\text { Age of patients } \\
\text { (years) }\end{array}$} \\
\hline$\leq 25$ & 2.867 & 0.739 & 0.000 & $\begin{array}{c}1.729- \\
4.754\end{array}$ \\
\hline $26-30$ & 2.906 & 0.569 & 0.000 & $\begin{array}{c}1.978- \\
4.268\end{array}$ \\
\hline $31-35$ & 2.640 & 0.503 & 0.000 & $\begin{array}{r}1.816- \\
3.836\end{array}$ \\
\hline$>35$ & 1 & & & \\
\hline \multicolumn{5}{|l|}{ Type of infertility } \\
\hline Infer II & 0.909 & 0.127 & 0.499 & $\begin{array}{l}0.691- \\
1.197\end{array}$ \\
\hline Infer I & 1 & & & \\
\hline \multicolumn{5}{|l|}{ Illegal abortion } \\
\hline $1-2$ & 0.586 & 0.100 & 0.002 & $\begin{array}{l}0.419- \\
0.820\end{array}$ \\
\hline$\geq 3$ & 0.329 & 0.141 & 0.009 & $\begin{array}{l}0.142- \\
0.762\end{array}$ \\
\hline none & 1 & & & \\
\hline \multicolumn{5}{|l|}{ Partner age (years) } \\
\hline$\leq 30$ & 1.714 & 0809 & 0,254 & $\begin{array}{c}0.679- \\
4.324\end{array}$ \\
\hline $31-40$ & 2.002 & 0714 & 0,052 & $\begin{array}{l}0.995- \\
4.029\end{array}$ \\
\hline $41-50$ & 0.578 & 0222 & 0,155 & $\begin{array}{l}0.272- \\
1.230\end{array}$ \\
\hline$>50$ & 1 & & & \\
\hline $18.5-24.9$ & 0.525 & 0.331 & 0.307 & $\begin{array}{l}0.152- \\
1.808\end{array}$ \\
\hline $25-29.9$ & 0.520 & 0.107 & 0.002 & $\begin{array}{l}0.347- \\
0.779\end{array}$ \\
\hline$\geq 30$ & 0.442 & 0.119 & 0.003 & $\begin{array}{l}0.260- \\
0.752\end{array}$ \\
\hline$<18.5$ & 1 & & & \\
\hline \multicolumn{5}{|l|}{ Diagnosis } \\
\hline Genital infection & 1.829 & 0.758 & 0.146 & $\begin{array}{l}0.810- \\
4.125\end{array}$ \\
\hline Myoma & 1.134 & 0.526 & 0.785 & $\begin{array}{l}0.456- \\
2.810\end{array}$ \\
\hline Ovarian Dystrophy & 3.289 & 1.555 & 0.012 & $\begin{array}{c}1.301- \\
8.311\end{array}$ \\
\hline Hyperprolactinemia & 4.902 & 2.350 & 0.001 & $\begin{array}{l}1.915- \\
12.548\end{array}$ \\
\hline Synechia & 2.038 & 1.345 & 0.281 & $\begin{array}{c}0.559- \\
7.429\end{array}$ \\
\hline Menopausis & Omitted & & & \\
\hline Cycle desorders & 3.668 & 2.197 & 0.030 & $\begin{array}{l}1.133- \\
11.869\end{array}$ \\
\hline $\begin{array}{l}\text { Others } \\
\text { HSG }\end{array}$ & 1 & & & \\
\hline ВТО & 0.814 & 0.172 & 0.332 & $\begin{array}{l}0.537- \\
1.233\end{array}$ \\
\hline UTO & 0.689 & 0.210 & 0.223 & $\begin{array}{l}0.378- \\
1.254\end{array}$ \\
\hline Others & 0.459 & 0.142 & 0.012 & $\begin{array}{l}0.250- \\
0.844\end{array}$ \\
\hline $\begin{array}{l}\text { Normal } \\
\text { Endometrial biopsy }\end{array}$ & 1 & & & \\
\hline $\begin{array}{l}\text { Functional } \\
\text { abnormalies }\end{array}$ & 0.754 & 0.194 & 0.273 & $\begin{array}{c}0.455- \\
1.249\end{array}$ \\
\hline
\end{tabular}

\section{Discussion}

General Patients Characteristics

The average age of the patients was $33.2 \pm 5.6$ years raging from 18 to 49 . That was close to our findings in 2011: $33.7 \pm 5.2$ years old [19] . In the contrary, that mean age was superior to the ones, found by our team 15 years before [20], by Cissé et al., 1997 [21] and Moreira, 2008 in Senegal [17] respectively: 29.5; 26 and 28 years. That observation is consistent with Belaish et al., 2009 who noticed the increase of age at first motherhood year by year, in the world. Many women get married more and more later [22]. Furthermore, the high rate of illegal abortions among patients (40\%) pleads for great sexual activity meanwhile, without contraception barrier, that constituted a risk factor for sexual transmitted infection and its consequence leading to tubal infertility.

The mean duration of infertility was ranged from 1 to 25 Years with an average of $4.3 \pm 3.7$ years, comparable to our findings in 2011 [19] and Stacey in USA among blacks patients and Hispanics in comparison with white American and those of Chinese origin [23] . The long duration of infertility could be explained not only by ignorance and poverty, but mostly by the patients' itinerary. They go for alternative medecine (traditional medicine providers) first before relying on western medicine [19] .

2) Conception after Management

Nine percent of infertile patients conceived (clinical pregnancy). Considering only the patients who persevered to 
the beginning of paraclinical investigation (HSG), (1219 patients), the conception rate climbed to $11.09 \%$. In comparison to Western ARTs centers results, that rate is, naturally very low [11] . No conception occurred in patients, whose partners were azoospermia or with OAT and the ones with history of tubal reparative surgery.

The mean age of the conception group $(31.3 \pm 5.7$ years $)$ was significantly $(p=0.000)$ lower than controls $(33.4 \pm 5.6$ years). Conception rate was $11 \%$ in group of patients less than 36 years old and $4 \%$ above. Considering the association between conception and predictors, the patients less than 36 years old had three times more chance to conceive than those above $(\mathrm{p}=0.000)$. Noticed in univariate analysis, that association persisted in the multivariate analysis. Adjusted with other predictors effects, patients of less than 25 years old had 24 times more chance to conceive than those above 35 years old $(p=0.017)$. That is consistent with the progressive decrease of female fertility from age of 30 according to Broeckmans et al., 2007 curve [24]. This is mainly explained by ovarian ageing and the occurrence of pathologies related to female ageing, like myomas and endometriosis [25] . And we have to take in account, the high risk of tubal infertility due to risky sexual behavior (STI and VIH) of patients before maternity desire, illustrated by a high rate of illegal abortion.

The rate of conception declined significantly $(p=0.000)$ with the duration of infertility: $21.5 \%$ for patients with one year and $6.9 \%$ for patients of more than 5 years. Furthermore, patients seeking infertility care after one, two and 3 - 5 years clusters had respectively 4, 3 and 2 times more chance to conceive in comparison with those who consulted more later $(p=0.000$ and $p=0.062)$. That decreasing of the chance of conception is consistent with the decrease of fecundability according to the duration of fertility as stated by Schwartz [26]. Indeed, if the fecundability is around $25 \%$ at the beginning [24] , it falls by $16 \%$ after 6 months, $8 \%$ after 2 years and $4 \%$ after 5 years. That could be explained by the fact that longer is the duration of infertility, more likely the patients are aged. According to previous study in France, $44 \%$ of infertile women aged more than 40 years had more than six years of infertility. In addition, female and male gametes alterations and the reduction of intercourse frequency by ageing reduce the chance of conception per cycle [27] .

The mean age of the partners case $(37.8 \pm 5.7$ years $)$ was significantly lesser $(\mathrm{p}=0.000)$ than the controls $(40.5 \pm 6.0$ years $)$. The patients whose male partners were lesser than 41 years old had three times more chance to conceive than the elder ones $(p=0.05)$. That situation can be explained by the decrease of the sperm quality with the age, because of the alteration of spermatogenesis and vascularization related to testicular ageing. It is reported the decrease of Leidig cell number with reduction of testosterone production and increase of tissue fibrosis [28] .

In the USA, Fisch et al., 1996 noticed the reduction of sperm motility of $0.17 \%$ from the age of 30 years [29] . Furthermore, Anger et al., 1995 noticed the decrease of sperm motility of $0.6 \%$ to $12 \%$ and the increase of sperm abnormal form, from $0.9 \%$ to $18 \%$ between 30 to 50 years [30] .

The majority $(51.7 \%)$ of the patients who conceived were norm weighted, a few $(13.9 \%)$ were obese and underweighted $(2.8 \%)$. Compared to underweighted patients, the chance of conception decreased by $50 \%(\mathrm{p}=$ $0.002)$ for overweighed and $60 \%(\mathrm{p}=0.003)$ for obese. Furthermore, adjusted to other factors, overweight reduced the chance of conception by $95 \%(\mathrm{p}=0.033)$ compared to underweighted patients. Age of the patients seemed to explain partially that observation. Indeed, $75 \%$ of underweighted patients were younger than the overweighed and obese, who were older than 35 years. Gensik et al., 2007 [31] and Brewer et al., 2010 [32] in USA, noticed the reduction of the chance of conception by $18 \%$ among over weighted and obese patients in comparison with the norm weighted $(\mathrm{OR}=0.92$ and 0.82$)$.

A tenth $(11.03 \%)$ of patients with bilateral tubal occlusion conceived after treatment. In the current study, the main treatment of tubal occlusion was hydrotubation, which was also a treatment associated with conception. The occurring of conception in this situation poses also the problem of the validity of HSG findings compared to the laparoscopic ones [33] Indeed, in all studies related to this aspect it was noticed that HSG was more specific than sensible, with a high rate of false positive results [33].

No conception had been noticed among couple whose male partner had OAT and azoospermia; situations that can be resolved quasi exclusively by ART [34] .

Among the patients who conceived, $37.5 \%$ had genital infection as main diagnosis followed by the ones without any diagnosis $(24.8 \%)$, and there were $12 \%$ with hyperprolactinemia and $11.4 \%$ each with myoma and ovarian dystrophy.

Genital infection was the most frequent diagnosis for all patients (46.4\%). Furthermore, almost half of partner spermogram had leucocytospermia $(46.4 \%)$ and the majority $(52.84 \%)$ had other spermogram abnormalities associated with leucocytospermia, the best stigma of infection. It is well known that infection and its consequences (tubo-peritoneal, ovarian dysfonction) were the main responsible of infertility in subsaharan setting [7] .

Antibiotherapy was the most frequent treatment immediately associated with conception apart from some conception that occurred after some old fashioned techniques like hydrotubation.

The limit of the current study is its retrospective design, that could not allow to explore some predictors; Despite this weakness, in the other hand its strength is the huge number of patients 


\section{Conclusion}

In conclusion, to take care of infertile couple out of ART, the conception is more likely to occur in patients aged less than 36 years, with infertility duration less than 3 years, normal weighted, without history of illegal abortion and tubal surgery, suffering from genital infection; a partner of less than 41 years old, without OAT and azoospermia. The main treatment closely related to conception was antibiotics, followed by hydrotubation and ovarian induction.

\section{References}

1 Nana, P.N., Wandji, J.C., Rfornulu, J.N., Mbu, R.E., Leke, R.J.I. and Woubibwou, J.M. (2011) Aspect psychosociaux chez les patientes infertiles à la Maternité Principale de l'Hopital Central de Yaoundé. Clinics in Mother and Child Health, 8, C100601.https://doi.org/10.4303/cmch/C100601

2 Okonofua, F.E. (1996) The Case against New Reproductive Technologies in Developing Countries. British Journal of Obstetrics and Gynaecology, 103, 957-962.https://doi.org/10.1111/j.1471-0528.1996.tb09542.x

3 World Health Organization (2004) Infecundity, Infertility and the Childlessness in Developing Countries. Demographic and Health Surveys (DHS) Comparative Report No. 9. WHO, Geneva, 74.

4 Boivin, J., Bunting, L., Collins, J.A. and Nygren, K.G. (2007) International Estimates of Infertility Prevalence and Treatment-Seeking: Potential Need and Demand for Infertility Medical Care. Human Reproduction, 22 , 1506-1512.https://doi.org/10.1093/humrep/dem046

5 Fathalla, M.F. (1992) Reproductive Health: A Global Overview. Early Human Development, 29, $35-$ 42.https://doi.org/10.1016/0378-3782(92)90055-L

6 Ombelet, W., Cooke, I., Dyer, S., Serour, G. and Devroey, P. (2008) Infertility and the Provision of Infertility Medical Services in Developing Countries. Human Reproduction, 14, 605621.https://doi.org/10.1093/humupd/dmn042

7 Gwet Bell, E. (2013) Traitement médical de la femme infertile en Afrique. Reproduction Humaine et Hormones, $3-4,50-58$.

8 World Health Organization. Global Prevalence of Infertility, Infecundity and Childlessness. http://www.who.int/reproductivehealth/topics/infertility/burden/en

9 Mahmoud, A. L'infertilité au Maghreb: Aspect Statistiques. http://www.3cetudes.com/news/Infertilite au Maghreb aspect statistique.pdf

10 Nachtigall, R.D. (2006) International Disparities in Access to Infertility Services. Fertility and Sterility, 85, 871-875.https://doi.org/10.1016/j.fertnstert.2005.08.066

11 Mayenga, J.M. (2013) Quelle technique d'assistance médicale à la procréation pour l'Afrique? Reproduction Humaine et Hormones, 3-4, 96-103.

12 United Nations (1995) Report of the International Conference on Population and Development, Cairo, Egypt, 5-13 September 1994. United Nation Population Fund, New York, E. 95. XIII. 18.

13 Howard, W.J., Cooke, I., Kempers, R., Brinsden, P. and Sauders, D. (2010) International Federation of Fertility Societies IFFS Surveillance.

14 L’aide Médicale à la Procréation.http://www.chu-tours.fr/site_public/infos_sante/amp.html

[15] Horde, P. Connaitre le taux de réussite des FIV dans les centres de PMA.http://www.Santé-Médecine.net, 2003-12-4.

16 Murage, A., Muteshi, M.C. and Githae, F. (2011) Assisted Reproduction Services Provision in a Developing Country: Time to Act? Fertility and Sterility, 96, 966-968.https://doi.org/10.1016/j.fertnstert.2011.07.1109

17 Moreira, P., Fall, C., Dieng, T., Fall, A., Diouf, A. and Moreau, J.C. (2008) Assistance Médicale à la procréation: Indication et perception par les couples présentant une infertilité au centre hospitalier universitaire de Dakar. Mali Médical, 23, 50-56.

18 World Health Organization (2000) Obesity: Preventing and Managing the Global Epidemic. WHO, Geneva, 894.

19 Mboloko, E., Nzau, N.E. and Lokengo, L. (2011) itinéraire de la femme kinoise à la recherche des soins d'infertilité. Annals of African Medicine, 4, 855-863.

20 Mboloko, E.J., Yanga, K., Nguma, M., Lusanba, D., Kabwe, M., Tshiamu, B., et al. (1996) Les lésions tubaires et péritonéales à la coelioscopie chez les femmes stériles aux cliniques universitaires de Kinshasa. Panorama Médical, 1, 796-796.

21 Cissé, C.T., Cissé, M.L., Moréira, I.V., Dionne, P. and Diadhou, F. (1997) Maladies sexuellement transmissibles et stérilité féminine au CHU de Dakar: Prise en charge et moyens de prévention. Concept Fertil Sex, 25, 58-63.

22 Belaisch-Allart, J., et al. (2009) Infertilité dite inexpliquée: Quel bilan en 2009? Collège National des Gynécologues et Obstétriciens francais. Extrait des mises à jour en Gynécologie Médicale. 7-19.

23 Stacey, A., Misser, Sc.D., David, B.S. and Tarun, J. (2011) Cultural Factors Contributing to Health Care Disparities among Patients with Infertility in Midwestern States. Fertility and Sterility, 95, 1943- 
1949.https://doi.org/10.1016/j.fertnstert.2011.02.039

24 Broekmans, F.J., Knauff, A.H., Egbert, R., Veide, T., Macklon, N.S. and Fauser, B.C. (2007) Female Reproductive Ageing: Current Knowledge and Future Trends. Trends in Endocrinology and Metabolism, 18, 58-65.https://doi.org/10.1016/j.tem.2007.01.004

25 Mboloko, E., Muhindo, M., Ingala, A., Nzau, N.E., Lokengo, L.D., Bikuelo, B., Kapend, M.M.M. and Mboloko, M. (2017) Uterine Leiomyoma in an Infertile Population in Kinshasa (DR Congo). Annals of African Medicine, 10, 2635-2642.

26 Schwartz, D. (1981) Importance de la durée d'infécondité dans l'appréciation de la fertilité du couple. Population, 2, 237-250.https://doi.org/10.2307/1532547

27 Zorn, J.R. and Savale, M. (2005) Stérilité du couple: Assistance Médicale à la Procréation. Masson, Paris, 19,285-320.

28 Belaisch-Allart, J. (2002) Désir de grossesse et déclin de la fertilité. Collège National des Gynécologues et Obstétriciens francais. Extrait des mises à jour en Gynécologie Médicale. 60-71.

29 Fisch, H., Goluboff, E., Olson, J., Feldshuh, J., Broder, S. and Barad, D. (1996) Semen Analyses in 1283 Men from the United States over a 25-Years Period: No Decline in Quality. Fertility and Sterility, 65, 10091014.https://doi.org/10.1016/S0015-0282(16)58278-8

30 Auger, J., Kunstmann, J.M., Czyglik, F. and Jouannet, P. (1995) Decline in Semen Quality among Fertile Men in Paris during the Past 20 Years. The New England Journal of Medicine, 332, 281285.https://doi.org/10.1056/NEJM199502023320501

31 Gesink Law, D.C., Maclehose, R.F. and Longnecker, M.P. (2007) Obesity and Time to Pregnancy. Human Reproduction, 22, 414-420.https://doi.org/10.1093/humrep/del400

32 Brewer, J.C. and Baleen, A.H. (2010) The Adverse Effects of Obesity on Conception and Implantation. Reproduction, 140, 347-364.https://doi.org/10.1530/REP-09-0568

33 Mboloko, E.J., Yanga, K., Nguma, M., Mputu, L. and Wolomby, M. (1998) La validité des résultats de l'hystérosalpingographie dans l'exploration de la stérilité du couple aux Cliniques Universitaires de Kinshasa. Congo Médical, 2, 408-411.

34 Davuluri, S. (2018) Current Trends in Management of Azoospermia and Oligoasthenospermia. In: Rao, K.A., Ed., The Infertility Manual, Jaypee Brothers Medical Publishers, New Delhi, 140-145. 